\title{
PERSIUS ON POETIC (IN)DIGESTION
}

\author{
J C Zietsman (University of Stellenbosch)
}

As a satirist, Persius is strongly opposed to the grand themes of epic and tragedy. In the first 29 lines of Satire 5 (cast in the form of a dialogue between the poet and his friend, Cornutus), Persius is mainly concerned with the style and themes of contemporary epic and tragedy (1-9), metaphorically linking the process of contemporary literary production (with special reference to tragic writers) and the consumption of ghastly, cannibalistic banquets dished up by tragic writers and actors. He then justifies his approach to his own poetry and the appropriate style for the satirist (10-29). Although reference will be made in passing to the whole of lines 1-29, this paper will focus on Satire 5:1-9 and 17-18 by discussing the meanings and nuances of key words first and then interpreting each pericope as a unit.

\section{Lines 1-4: A statement by Persius}

1 uatibus hic mos est, centum sibi poscere uoces,

2 centum ora et linguas optare in carmina centum,

3 fabula seu maesto ponatur hianda tragoedo,

4 uolnera seu Parthi ducentis ab inguine ferrum.

This is the poet's age-old cry: "Give me a hundred voices, / a hundred mouths, and a hundred throats for my songs!", / whether they're presenting a play to be mouthed by a dismal tragedian, / or the image of a wounded Parthian pulling a spear-head from his groin. ${ }^{1}$

In the opening lines of Satire 5 Persius states the traditional themes of contemporary epic and tragedy, starting with a reference to the habit of poets to request a 100 voices, a 100 mouths, and a 100 tongues with which to declare their poems and so that they can do justice to a lofty theme (Morford 1984:55; Ramage 1974:112). This motif began with Homer and, continuing throughout epic poetry, it was used to indicate difficulty of expression. Homer had more modestly called for only ten tongues and ten mouths in Iliad 2.489. In the first century BC the epic poet Hostius (a contemporary of Caesar) increased the number to a 100 (Conington 1874:82; Morford 1984:114), as did Vergil in Georg. 2.43 and Aen. 6.625. ${ }^{2}$ Although the motif is originally used to indicate difficulty of expression, Vergil probably uses it also to indicate the importance or greatness of a theme. Persius' interpretation of this motif is that it could also indicate loud, bombastic grandiloquence since it refers to poets of the lofty genres of tragedy and epic (3-4) from which he has already dissociated himself in his prologue and in the programmatic first satire.

In the prologue to his satires, Persius strongly criticises poets who seek inspiration from the Muses and who write poetry in the foreign Greek tradition:

1 nec fonte labra prolui caballino

2 nec in bicipiti somniasse Parnaso

3 memini, ut repente sic poeta prodirem.

4 Heliconidasque pallidamque Pirenen

1. I have used Clausen's edition for quotations from Persius. Translations of passages quoted are based on Rudd.

2. For other instances of the motif in epic poetry see Enn. Ann. 561-562;(V. ); Ovid Met. 8.533-534 and Fasti 2.119-120; Stat. Th. 12.797-798; Sil. 4.525-526; Val. Fl. 6.36-37. 


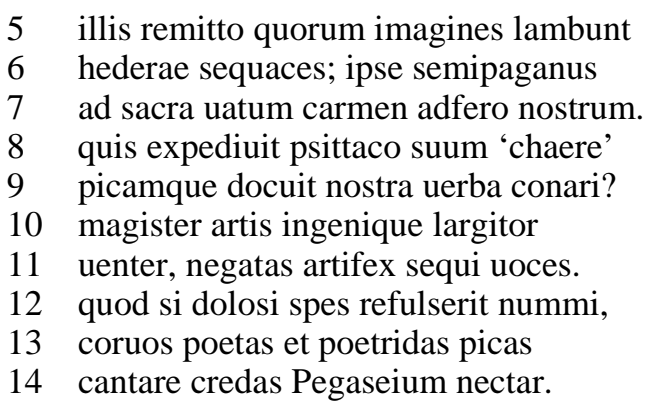

I never drenched my lips in the fountain of the nag, nor had any dreams that I recall on two-peaked Parnassus to justify this sudden entry on the poetic scene. As for the maids of Helicon, and blanching PireneI leave them to men who have clinging ivy licking their busts. It is as only a half-clansman that I bring my song to the holy rites of the bards. Who made the parrot so ready to squawk "Hello!"? Who helped the magpie to cope with human speech? It was that teacher of art, that donor of talent - the belly, with its gift for producing words unintended by nature.

If cash sends out an alluring ray of hope, you'll find raven poets and magpie poetesses carolling nectar worthy of the Muses' steed.

The prologue is divided into two equal parts (1-7 and 8-14), linked by the motif of Pegasus which appears in the first and last lines. The first half deals with Persius himself as a writer of satire and the second half with poets in general. These two halves are linked by the theme of poetic inspiration. In the first half, the underlying theme is divine inspiration, and in the second poetic inspiration provided by monetary gain. Persius refuses to pay lip service to the traditional metaphors of poetic inspiration. The Muses, the Greek goddesses of poetry, were said to inhabit Hippocrene, the fountain (fonte . . caballino, 1) on Mount Helicon opened by a stroke of Pegasus' hoof. Mount Parnassus (2) was sacred to Apollo, the patron of poetry. Drinking (prolui, 1) from the fountain of the Muses as well as dreaming on Mount Parnassus (somniasse, 2) were traditional metaphors for poetic inspiration. The satirist therefore rejects the motif of the poet receiving his initiation as a poet from divine sources, not only because it denies conscious craftsmanship and the hard work that goes into writing poetry (ut repente sic poeta prodirem, 3) but, equally important, because it is of Greek origin.

His disapproval of the Greek tradition is already apparent when, in the first line, he calls the Hippocrene fountain fons caballinus. By Persius' time the difference between equus and caballus lay not in meaning, but in level or tone; caballus is the word which was becoming normal in popular or vulgar speech and equus is the upper-class or literary word. By using the vulgarism Persius thus derides epic pretensions, and it is indeed the essence of satire to do so. Persius' rejection is carried further when he suggests that a dream like that of Ennius about Homer can be forgotten — nec in bicipiti somniasse Parnaso / memini (2-3) - and thereby denies himself any inspiration by the Muses.

In these three lines, therefore, Persius uses the traditional symbols for poetic inspiration to dissociate himself from the lofty genre of epic. By rejecting divine inspiration, he places his satire on a "lower" level than other forms of poetry, and he emphasises the earth-bound nature of satire (cf. Horace’s pedestrian mouse in 2.6.17). 
Persius, however, dissociates himself not only from the famous Greek poets and from the early Roman poets like Ennius who imitated Greek models (prol. 1-6a), but also from his contemporaries who are inspired by the Muses and who are slavishly continuing with this imitation of traditional epic and tragedy (8-14). Before doing so, however, he ends the first half of the prologue with a positive statement: ipse semipaganus / ad sacra uatum carmen adfero nostrum (6b-7). He uses the traditional term uates for poets and adapts the common metaphor of the poets' calling as a sacred ritual to deflate his own satire (Morford 1984:27). $\mathrm{He}$ is semipaganus ("half-initiated") because he cannot fully participate in the poets' mysteries, as he does not share the divine inspiration of the epic and lyric writers, but draws his inspiration from the everyday world of the common man (a claim repeated in 5.14, uerba togae sequeris.)

The themes of divine poetic inspiration (1-7) and monetary poetic inspiration (8-14), built around bird-imagery, ${ }^{3}$ are brought together in line 10, where ars ("technical mastery") and ingenium ("genius") ${ }^{4}$ are ironically combined: the master of technique and the giver of inspiration is the stomach (10-11). A fundamental problem for literary critics (including satirists) was to decide the relative merits of inspiration and technique. Persius here discusses it with the ironic statement that it makes little difference, because being able to earn a meal by their writing (their talent comes from the belly, uenter, 11) is all that matters to poets and versifiers.

The theme of Persius' rejection of contemporary poets and their poetry is worked out at great length in his first satire. The purpose of Satire 1 is to give Persius' apologia for writing satire and to distinguish his poetry from the inferior literary activity of his contemporaries. The corruption of contemporary literature is shown to be inextricably linked to moral corruption, so that the wider theme of the moral weakness of Rome underlies the satirist's literary apologia. Lines 1-12 justify Persius' writing of satire because contemporary standards of judgement are worthless. This apologia is followed by fierce criticism of contemporary poets, arguing that the poets are pretentious and lust for applause (13-43), while the satirist on the other hand will earn such applause as he can because his standards are true and his self-criticism rigorous (44-62). In 63-106 Persius quotes examples of modern literary themes, style and technique, and ridicules them as frivolous products of literary dabblers and not the result of a true poet's labours. The satirist finally justifies his criticism (107-134) by appealing to the examples of Lucilius and Horace. His discovery of the rottenness of contemporary standards is a secret, to be shared only with those few who appreciate the honest criticism of the satirical tradition.

One extract from Satire 1 will suffice as an illustration: in lines 32-35 Persius deals with the effeminate quality of contemporary poetry. By describing the performance of the poet who is reciting his work to an audience, Persius points to the sentimental treatment admitted by the themes of elegy:

32 hic aliquis, cui circum umeros hyacinthina laena est,

33 rancidulum quiddam balba de nare locutus

34 Phyllidas, Hypsipylas, uatum et plorabile siquid,

3. The parrot and the magpie are well-known imitators. For the practice of keeping parrots and magpies in great houses, see Plin. N.H. 10.117-120; Mart. 14.73 and 76; Petronius 28.9, super limen autem cauea pendebat aurea, in qua pica uaria intrantes salutabat. Besides being an imitator, the crow is a symbol of foolish pretension, the character in which it appears in one of Aesop's fables.

4. These terms were basic in the debates about poetry that began in Alexandria early in the third century BC and still continued in Persius' day (Morford 1984:26). 
35 eliquat ac tenero subplantat uerba palato.

Then a creature with a hyacinth mantle draped around his shoulders / mumbles some putrid stuff though his nose, / filtering out a Phyllis or Hypsipyle or some other tear-jerking bardic rot, / letting the words trip prettily against his tender palate.

These lines resume the motifs introduced in the earlier descriptions of the recitations, namely that poetic activity is an affectation, and its practitioners and its admirers are no more than effeminate frauds (Morford 1984:33). In 15-23 Persius actually goes so far as to equate the reciting of poetry with sexual gratification for both poet and audience. Here, in 33, poetry is metaphorically seen as food dished up at a banquet. The "poetic food" is called rancidulum, a word which carries a strong negative connotation ("disgusting, loathsome, offensive”): carmen quoddam putidum, fastidium afferens, ineptum (Bo 1967 ad 1.33). The effeminate nature of this inferior poetry is reflected in the phrases balba de nare (33) - which Bo explains as ita loquebantur effeminati ${ }^{5}$ — and eliquat ac tenero subplantat uerba palato (35). Both eliquat, i.e. artificiose, nimis molliter pronuntiat (Bo 1967 ad 1.35) and tenero ("soft, delicate, tender") point to the effeminacy of the reciter.

To return to the opening lines of Satire 5: although centum . . . uoces may originally have referred to the needs or wishes of the epic poets, Persius applies it also to contemporary tragedy - a genre to which he is strongly opposed because of its banality. His opening statement in 1-4 must therefore be seen as the opposite of an appeal to the Muses: by sneering at the obsolete topics of epic and tragedy (3-4), he is at the same time (although not expressis uerbis) suspicious about the poets' inspiration for writing such nonsense and implies that he would not attempt to claim the same inspiration for himself. Furthermore, and especially against the background of his arguments in the prologue and Satire 1, his implication is that he will write in a different genre and on a different topic. His reason for referring to a hundred mouths is therefore to indicate his disapproval of the motif and to make it seem ridiculous.

The poet's disapproval is emphasised by the repetition of centum in the first two lines. Persius is here imitating Vergil who greatly favours anaphora of centum, using it - besides in his hundred-mouth formula - to reinforce the impression of large numbers (see Georg. 4.383, Aen. 1.634-635, 4.199-200 and 7.93). In 1-2 centum is stressed by position in all three instances: in the first line centum is placed immediately after the caesura; the second centum introduces the second line, while the third centum is also emphatic as the last word in the line. For Persius the formula is a cliché and he seems deliberately to exaggerate the motif, thereby mocking it. ${ }^{6}$

In lines 3-4 Persius refers to the topics treated by contemporary poets, namely tragedy (fabula, 3) and epic (uolnera ... Parthi, 4). Although fabula actually simply means "a dramatic poem, drama, play" the context in which it appears here (maesto ponatur hianda tragoedo) narrows the reference to that of tragedy: hianda refers to the mask worn by the tragic actor.

The gaping mouth tends to be associated with turgid and grotesque literary composition: the expression of intention to write in high style is succeeded by an image of a gaping mouth, so dissolving pretension by ridicule (see also Juv. 6.636, grande Sophocleo carmen

5. See also Van Wageningen (1911) ad loc. and Hor. Sat. 2.3.274, cum balba feris annoso uerba palato. Conington 1874:15 explains the phrase as implying “. . . an affectation of tenderness”.

6. The reader is once again referred to Homer (Iliad 2.489) who modestly called for only ten tongues and ten mouths. 
bacchamur hiatu.) It seems that Persius' application of hianda here is specifically pejorative. His description of the gaping mouth of the mask worn by the tragic actor also refers to the grotesqueness of the themes treated by his contemporaries (uolnera . . Parthi, 4).

The epithet maesto ... tragoedo (3) is another reference to tragedy. Together with hianda, the phrase once again refers to the appearance of the actor's mask and suggests that tragedy was not confined to literary groups at this time but was still performed in theatres.

The verb ponatur (3) is of extreme importance in the development of the metaphorical allusions to food that will be discussed later. At this stage, it is necessary to look only at the primary meaning of the word as componatur or scribatur (Bo 1967:82). Conington (1874:83) argues that it does not mean "to set up a thing as complete" (1.70 and 1.86) but "to set before one as a thing to be done".) As a result of the specific reference of ponatur to fabula (3) and uolnera (4), the sense of the verb can also be explained as "describatur, canatur". This corresponds with the explanation of ponatur as "to produce a tragedy" in the Greek sense (Pretor 1907:62). The meaning of ponatur in this context can therefore be construed as indicating not only the process of writing or composing or that of reciting literature, but also of the staging of a play.

The reference in uolnera ... Parthi (4) is to epic poetry: Parthians are considered epic material by inter alia Hor. Sat. 2.1.15 and Ovid A.A. 1.205-212. The picture of the Parthian receiving a wound in the groin may refer to a lost literary work, but is more probably a simple conflation of an epic theme, the Parthians, and an epic motif, the wound in the groin. This motif is frequently found in Homer and was taken over by Roman epic (Harvey 1981:125-126. See for example Verg. Aen. 10.589; Ovid Met. 5.132).

A final word remains to be said on the composition of lines 1-4. Structurally this pericope consists of only one sentence, in which Persius significantly uses certain key words in emphatic positions: uatibus, centum, fabula and uolnera all appear at the beginning of each of the first four lines respectively: poets need a hundred mouths for tragedy and epic. On reading 1-4 once again, it becomes clear that Persius limits the topics treated by his contemporaries to tragedy (fabula) and epic (uolnera), topics that he rejects just as strongly as he rejects the poets (uatibus) who claim divine poetic inspiration.

\section{Lines 5-9: Cornutus questions the themes of contemporary epic and tragedy}

5 'quorsum haec? aut quantas robusti carminis offas

6 ingeris, ut par sit centeno gutture niti?

7 grande locuturi nebulas Helicone legunto,

8 si quibus aut Procnes aut si quibus olla Thyestae

9 feruebit saepe insulso cenanda Glyconi.

"What's the point of all this? What lumps of nutritious verse / are you cramming in, that you need a hundred throats to deal with them? / Bards committed to the elevated style may gather mists on Helicon, / those who intend to bring Procne's or Thyestes' pot / to the boil to provide a regular supper for tasteless Glyco.

Cornutus' reaction (5-9) is a humoristic and sarcastic answer to Persius' statement in 1-4 (referred to by haec, 5): "It is indeed grand poetry that you want to recite if you need a 100 mouths to do so!" (Conington 1974:83; Némethy 1903:236). From the references used by Cornutus, it is clear that he is criticising the themes of contemporary poetry and is warning Persius especially against tragedy. For Cornutus tragedy involves expressing obsolete and 
well-worn myths in pompous language (Harvey 1981:126). His words could be a reference to the exaggerated and grotesque works of the professional poets in Persius' time, especially to that of Lucan and Silius Italicus, as well as to Seneca's horrific treatment of the gruesome Thyestes myth of which Persius must have been aware.

In line 5 offas is used in a distinctively negative sense. The basic meaning of the word is "a piece, lump, chunk, mass", and carminis offas seems to mean "long passages of poetry". However, offas is typically used by poets of the high style (Enn. Ann. 526; Verg. Aen. 6.420) who have just been rejected by Persius (1-4). The effect of its application here is therefore that of irony. Equally ironic is quantas, which does not only refer to the extent, but metaphorically also to the greatness of the poetry. An important aspect in this line is that carminis is qualified by robusti, meaning "strong, powerful". (For Cicero De Or. 91 and Quintilian 12.10.58 robustus denotes the highest genera dicendi.) The irony of Cornutus' question is now finally clear: he is describing epic and tragedy as large chunks of solid poetry. The irony is continued by ingeris (6) which means "provide, heap up" but which also suggests "say repeatedly, harp on": the themes of tragedy and epic are totally outworn.

In the phrase centeno gutture (6) Cornutus is mocking epic tone. The use of the singular distributive (centeno) for cardinals is rare (Harvey 1981:127) and strictly used for abuse in Latin. The phrase takes up the 100 mouth motif in 1-4 but the usage of gutture ("gullet, throat") with reference to the motif is probably also contemptuous since it does not occur as part of the formula elsewhere in classical literature.

The mocking effect of centeno gutture is emphasised by the verb niti, which is basically used in the sense of "to depend upon". However, there is a further suggestion of effort involved since the verb can also mean "to strive, to exert oneself, make an effort". It is in this sense of the verb that Conington (1874:84) explains the phrase gutture niti as "to press upon the throat”, as is done in a difficult swallow. Cornutus' sarcastic implication is therefore that the process of reciting contemporary tragedy and epic, that is "large chunks of solid poetry" (offas), is laborious.

In line 7 grande locuturi refers directly to the high genres of epic and tragedy (Conington 1874:84; Némethy 1903:237) although grandis seems to have been poetic jargon at Rome in Persius' time: Seneca uses the word several times (for instance in Epist. 48.11, 79.7, and 114.11; Quintilian also uses grandis with reference to high style in 12.10.58.) In the context of Cornutus' words, grande locuturi refers to the pompous and worthless themes of contemporary literature.

The application of nebulas (7) is capable of more than one interpretation. If it is taken closely with 8-9, it relates to worthless poetic themes such as the trite topics mentioned there by Cornutus. It can be taken as the object of both grande locuturi, which denotes the highest of the genera dicendi (i.e. epic and tragedy), and of legunto. In either way nebulas denotes the pompous themes of contemporary literature as well as an excessively elevated style and artificial language. Persius may have adapted Horace A.P. 229-230, as both are speaking of tragic writing and both combine the stylistic and literal implications of "high" style: the situation of the divinely inspired poets, i.e. "high on Helicon", means that they are likely to encounter clouds (Harvey 1981:127). With nebulas, Cornutus therefore refers to the contents of contemporary poetry - empty, worthless and without substance - and at the same time he suggests that it is dark, obscure, and unintelligible - a reference that is equally applicable to contemporary style.

In order for the poets to "collect mists", it would be necessary to ascend the mountain. The reference to Helicon (7) recalls not only the poet's rejection of the sources of inspiration to 
which his contemporaries lay claim (prol. 1-4), but also his criticism of the affected recitation of compositions in prose and verse to the public in Satire 1. The implication of Cornutus' words here seems to be that an invocation of the Muses would lead to the same kind of poetry as that written by Persius' divinely inspired contemporaries: both stylistically and thematically it would be grande, the unsubstantiated and obscure traditional themes as represented here by the horrible myths of Procne and Thyestes (8-9), common subjects of tragedy in Rome as well as in Athens. Procne is mentioned in Hor. A.P. 187 and Juv. 7.12 and 73. The feast of Thyestes is twice mentioned by Horace as a stock tragic subject (A.P. 91 and 186) and is also referred to in Juv. 8.228 and Tac. Dial. 3.2. Seneca's horrific treatment of the gruesome myth is probably the best known. Martial ridicules the story for its unreality in 4.49.4, 5.53.1, 10.4.1, 10.35.6.

Procne was the wife of Tereus who forced Philomela, Procne's sister, to marry him after he had falsely told her that he had received news of Procne's death. When Philomela learned the truth and threatened Tereus, he seized her and cut out her tongue, telling Procne that Philomela had died. Procne, however, eventually discovered Tereus' deceit and decided to punish her husband by killing their son, Itys, whose body she cut up, cooked the limbs and served them to Tereus for supper (Ovid Met. 6.424-674).

The phrase olla Thyestae refers to the two brothers, Atreus and Thyestes. The latter fell in love with his brother's wife and succeeded in making her break her marriage vows. When Atreus found out that his wife was having an adulterous relationship with Thyestes, he swore that Thyestes would suffer a horrible punishment. Atreus then killed his brother's two little children, had them cut limb from limb, boiled, and served up to their father.

Cornutus' reference to these two gruesome and grotesque myths constitutes a very damning criticism of contemporary literature and at the same time, it defines grande locuturi and nebulas Helicone legunto in the previous line: the empty, worthless themes treated by contemporary poets are equally gruesome and grotesque. The verb feruebit (9) adds to the pejorative context of Cornutus' reference to the stock tragic themes: it has the suggestion of "boil up, foam, rage”.

According to the scholiast, Glyco (9) was a slave, the joint property of Vergilius, a tragic actor, and some other person. On account of his great popularity he was manumitted by Nero, who paid Vergilius 300000 sesterces for his share. Tall and dark, with a hanging lower lip, he was ill-looking when not dressed up, and he was called insulsus from his inability to understand a joke: Harvey (1981:128) explains insulso (9) as “apparently 'dull, boring'”. In the context of the references to the myths of Procne and Thyestes, the meaning of insulsus is obviously more pointed than such a general interpretation would allow. The meaning of insulsus applicable here is “tasteless, insipid”. Cornutus is referring to Glyco's insipidity - it is his lack of taste that allows him to play the part of Tereus or Thyestes and to present the grotesque themes of the gruesome myths.

In Vita Augusti 70 Suetonius uses cenat in the sense of "recite, present during a meal". With reference to the literary allusions in 5-9, cenanda can therefore be interpreted in the sense of agenda, meaning that Glyco regularly presents the stories of Procne and Thyestes by acting the parts of Tereus and Thyestes.

The recital or production of a literary work often took place during the cena (the main Roman meal) during which, in a cultured household, the diners were entertained by readings, music and humorous recitations. Such a household possessed one or more readers among its freedmen or slaves, often knowing the text of some author by heart. There were also 
freedmen or slaves, called comoedi, who recited passages from drama and whose profession was highly esteemed (see Plin. Epist. 1.15.2, 3.1.9, 9.17.3, 9.36.4).

The basic meaning of lines 8-9 is therefore that the tasteless Glyco presented or recited passages from the myths of Procne and Thyestes during the cena. For Cornutus the themes of these myths are typical of the obscure, worthless themes (nebulas, 7) treated by Persius' contemporaries - the poets who want to write in the high style (grande locuturi, 7) and who seek their inspiration from divine sources (Helicone, 7). By linking the horrible cannibalistic myths to the source of divine poetic inspiration, Persius' rejection of contemporary poetry gains a harshness that was not evident in even the strong words used in the prologue or suggested by his rejection of uates in 1-4.

This forceful rejection of contemporary poetry is (although only indirectly at first) emphasised by cenanda (7). A closer look reveals that cenanda suggests much more than Glyco's reciting or presentation of a drama during a banquet. The primary literary references in 5-9 culminate in cenanda, which on the secondary level of the satire, is the pivoting point for the metaphorical references to the preparation, serving and consumption of food that I have mentioned earlier.

With cenanda it finally becomes clear that Cornutus' words are ambiguous for they do not only refer to contemporary literature but also to literature as food. He retains this ambiguity throughout his speech (5-18) but especially in 5-9 of which the metaphorical allusions form an integral part. As a result of the food metaphor, the final effect of the speech is that Cornutus describes poetry as food: he humorously supposes that the 100 mouths and tongues requested by poets (1-4) are not for the purpose of poetic expression, but for devouring the tragedy or epic that is to be served up (5-9).

However, let us return to the opening lines of the satire: references to the food metaphor actually already appear in 1-4 and Cornutus' words in 5-9 are therefore merely a continuation of the metaphorical allusions in the first four lines of the satire in which a variety of metaphors of the mouth assist in the establishment of this imagery. Persius employs the metaphor of the mouth in a very active sense, not only as an organ of address or song, but also for eating, drinking and blowing.

In the first line uoces, ora and linguas effect an interplay between the two different images: the mouth is used for delivering poetry as well as for consuming food. This change of emphasis from poetry to food accompanies the transformation of centum ... uoces in the first line, with its dependence on the 100-mouth motif of epic, into centum ora et linguas ... centum in the second. These words create a progressively more physical emphasis (enhanced by the repetition of centum to which I have already referred) and realistic impression and therefore 1-2 mark a movement towards the food metaphor: "voice” becomes "mouth", then "tongue".

By using mouths and tongues (ora et linguas, 2) as the equivalent of voices (uoces, I) and by coupling these words with fabula seu maesto ponatur hianda tragoedo (3) - this phrase could potentially evoke the scene of a waiter setting a hearty meal before a banqueter (Anderson 1960:70) — Persius anticipates the images relating to food in $5 \mathrm{ff}$.

The ambiguous verb ponatur (3) is equally applicable to literary composition and to the serving of food. With reference to literature, it means componatur (see 1.70 and 86) but also stands for apponatur in the sense of "to serve up, set before one at a table" (Neméthy 1903:235). Persius uses ponere with the same meaning in 1.53 where he criticises the corrupt practice of wealthy poets who give dinners in order to secure an audience for their work. The 
implication of ponatur is therefore that poetry is presented at a table as if it is to be eaten and the verb as such anticipates cenanda (9).

Immediately following ponatur is the equally ambivalent hianda. It is used for the description of tragic recitation and writing, but also opening the gaping mouth; hianda may therefore also be related to the food concept as a closer inspection of the immediate context indicates. Since ponatur may convey the meaning of composing literature or of serving food, hianda must have connotations of both tragic performance and eating, or rather devouring. Both ponatur and hianda therefore carry a pejorative connotation because of the context, indicating a conflation between literature and eating.

This is made clear by 5-6 in which the earlier metaphorical allusions to a conflation between literature and food (1-4) are confirmed. Apart from referring to the highest of the genera dicendi, the adjective robustus also underlines the food association; although it is particularly used of persons, it is also commonly used of hearty, nourishing food. The idea involved in Persius is therefore that just as robustus cibus contains much nourishment, so tragic and epic poetry involve great poetic force, that is, the grand style. A specifically strong reference to the food metaphor is in the word offas (5) which means "a piece or chunk of food”. Commentators frequently quote Festus 282 (L), and Varro De Re Rust. 3.4 where offa means the food used to fatten birds. It also refers especially to a cake made from flour. On the other hand, it can also be applied in less pleasant contexts to indicate a swelling (Juv. 16.11) or an untimely birth or abortion (Juv. 2.23).

In terms of the food metaphor the phrase robusti carminis offas would mean something like "flour-balls of nourishing poetry". However, it could also be argued that Persius takes offas strictly in its literal meaning and applies it only to the high genres of poetry, to epic and tragedy, thus achieving "chunks of solid poetry" (see Petr. Satyricon 1, mellitos uerborum globulos). It is also of interest to observe that offa appears to belong to the vocabulary of epic: it is found in Ennius Ann. 526 and Vergil Aen. 6.419-421 uses the term of the morsel thrown as a sop to Cerberus: cui uates ... / melle soporatam et medicatis frugibus offam / obicit. Thus, the introduction of the word by Persius may be a deliberate epic reminiscence in a decidedly negative context.

Cornutus' description of contemporary epic and tragedy as "nourishing poetry" is however ironic when the metaphorical reference in ingeris (6) is taken into account. (Note that ingeris is stressed by position as the first word of the line.) The verb can be translated as "do you foist upon us" or "are you throwing at us", but is also used in the sense of "to pour into the body, take in, or cause to take in (food or drink, especially in large amounts)". The picture created is therefore one of large (quantas), solid (robusti carminis), edible chunks of poetry (offas) being swallowed by the mouth so that it would nourish (robusti) the brain (Pretor 1907:63). However, the "nourishing poetry" offered by contemporary poets consists of gruesome cannibalistic themes such as those of Procne and Thyestes (8-9).

The metaphorical reference in ponatur (3) and ingeris (6) is carried forward by gutture (6), meaning "gullet, throat" and is used with specific reference to appetite. Furthermore, the use of gutture, which does not occur previously in the 100-mouth formula to which Cornutus is mockingly referring with centeno gutture, reflects the shift of emphasis from poetic composition to ingestion: this image is parodied by supposing the mouth to be needed for eating, not for speaking, and thus we are prepared for the olla Thyestae (8).

Bramble (1974:55; see also Anderson 1960:70) interprets 5-6 as representing tragedy as coarse, edible chunks (offas) crammed (ingeris) into the mouth of the reciting poet (Conington 1874:84; Harvey 1981:126) and explains that the reference to the poet feasting 
himself (ingeris, 6) on the raw edible material of tragedy in preparation for regurgitated recitation, is implied by the change from uoces, ora and linguas to gutture: the poet has consumed great gobbets of tragedy, and now strains his throat during regurgitation. This interpretation however fails to grasp the subtle ambiguity within the metaphorical reference of ingeris, for although it may mean "ingest", a 100 mouths being required by the poet to consume his own poetry, it may also mean "provide, heap up”, tragedy being heaped up by the poet for other people to consume (Harvey 1981:127). Cornutus therefore asks what vast dish Persius is contemplating, a question to which the poet will reply in 19-25.

In 7-9 Cornutus contemptuously dismisses the horrible tragic themes treated by Persius' contemporaries, using the themes of Procne and Thyestes as his examples. The idea of poets consuming or serving up vast amounts of solid poetry (5-6) is temporarily set aside, but the food metaphor takes on a new and gruesome aspect through the introduction of the two wellknown cannibalistic myths.

Apart from the metaphorical allusions in these myths, references to the food metaphor also occur in olla (8), feruebit (9) and cenanda (9). The identification of poetic composition with ingestion is carried forward: olla, meaning "a pot or jar", has the same realistic tone as offas (5) and is confined in poetry to the lower genres. It is qualified by Thyestae that refers to the consumption of a gruesome cannibalistic meal (as does Procnes). The verb feruebit denotes the boiling of the pot and is specifically used of the boiling of cooking vessels while cenanda refers both to the tragedians' hideous concoctions and the horrible contents of the pot. Cicero Att. 13.31.4 uses insulsus in connection with gula to indicate a longing for tasteless things. In terms of the food metaphor, Glyco's insipidity takes on a new aspect: he longs for the tasteless, gruesome meals of Procne and Thyestes, which are not nourishing in the regular sense of robusti (5). The repeated " $s$ " in both 8 and 9 provides emphasis to the passage while other sounds (feruebit, cenanda Glyconi) even provide a phonic illustration.

Cornutus continues the metaphor of literary production and the preparation or consumption of food in 8-9 by proceeding to mock the two well-known banquets, to which he refers with the vulgar deflatory olla: tragedy becomes reduced to the ugly banquets of Procne and Thyestes. In Cornutus' imagery the myth that demands the gaping mouth of the tragic actor becomes the meal of Thyestes presented at a banquet by the actor Glyco. The metaphor of the poet as a cook serving up a meal of poetry to his audience also occurs in Greek and Roman comedy. However, Persius is probably not much influenced by such precedents. He excludes all mention of an audience and applies the idea of cooking not to poetry in general but to tragic themes that involve cooking. In doing so, he treats Procne and Thyestes as parallel characters, although they are not: Procne cooked her son and served the grisly meal to her husband, Tereus; Thyestes ate the gruesome meal consisting of the limbs of his two little children, prepared by his brother, Atreus. The parallel is therefore strictly between Tereus and Thyestes, and Persius' variation is apparently for its own sake.

To recap: the references to a conflation between literature and food are initially only vague suggestions (1-4) but gradually become more and more specific and direct (5-9) until the metaphor reaches a climactic point in cenanda (9). The literature recited during the luxurious and extravagant cenae of Persius' time (for example the Cena Trimalchionis described in Petronius Satyricon and the excessive banquets held by Nero) was quite often like the food served at the cena: excessive, rich, not always digestible, not nourishing and wholesome, but sensually appetising. Like the food, the literature is greedily devoured, but these literary dishes do not nourish, nor do they educate: literature is experienced sensually, not heard but gorged down by the throat. In contrast, Persius will write plain but nourishing prandia (17), 
literary dishes that nourish the mind (15-16) but have to be heard with the ears (62-64) and not experienced sensually.

This is then Persius' ambiguous game: contemporary literature is like food. The poet has an aversion to the literature of his time: it does not nourish the mind, but is merely sensual and sensational. He indicates his aversion by describing contemporary literature as the gruesome meals of Procne and Thyestes in order to create a repulsive nuance, a sense of abomination and disgust. But he is subtle, and therefore commentators (Bramble 1974:56; Harvey 1981:128) interpret Cornutus' words too literally when they say that Glyco dines on the meals of Procne and Thyestes at every production and that, reflecting his regular nightly supper, he is insulsus. Persius means that Glyco has a lack of literary taste (insulso, 9) when he recites these horrible themes at a banquet and that his recital is tasteless and insipid.

\section{Lines 10-13: Cornutus points out the defects of tragic style by indicating what Persius is not doing in the composition of his poetry}

10 tu neque anhelanti, coquitur dum massa camino,

11 folle premis uentos nec clauso murmure raucus

12 nescio quid tecum graue cornicaris inepte

13 nec scloppo tumidas intendis rumpere buccas.

You're different; you don't squeeze air from a bellows which gasps / as the furnace smelts the ore, or go in for hoarse, pent-up muttering, / inanely cawing some deep observation to yourself; / nor do you persist in blowing up your cheeks until they go bang.

Apart from tragic themes (5-9), Cornutus also attacks tragic style (10-13), protesting that such a style is alien to Persius' satires, and criticising the use of artificial verbiage. To him, tragedy involves expressing obsolete and well-worn myths in pompous language (Harvey 1981:126). Three distinct images are used, namely the bellows (10-11a), the croaking voice (11b-12), and the puffed cheeks (13). By using these three images, Cornutus contrasts Persius' poetry with that of his contemporaries: note that tu is emphatic by position as the first word in line 10. His indication of the three things Persius is not doing when writing his own poetry suggests that these are the three things done by the bombastic contemporary poets when composing their poetry: they seem to take great care but the result is that of a childish scloppo (13).

Only the first of these images relates to the food metaphor: the contemporary poet resembles the man operating the bellows at the forge to increase combustion. The image is meant to be generally pejorative: Persius may be indicting voluble style or he may be parodying poetic spiritus (as in 1.14), suggesting a pretentious mode of recitation (Némethy 1903:238).

His application of the image could also refer to the laborious and artificial process of literary composition during his time: the poet is described as squeezing (premis, 11) air (uentos, 11) from a pair of panting bellows (anhelanti ... / folle, 10-11). In other words, poetic composition is a forced process (premis), the product is empty and unsubstantiated (uentos, which refers back to nebulas, 7) and moreover it is artificial, poetry (like iron) being cast in a forge.

Cornutus has already spoken ironically of the mists of Helicon (nebulas, 7), but he effects a clear transition to the equally prejudicial idea of poetry as hot air by means of coquitur (10). However, coquitur is ambiguous since it also refers to the metaphor of poetry described in 
terms of the preparation of food. The image of the bellows is therefore the instrument that unites the metaphors of poetry as hot air and poetry as food: the air in the bellows is hot because of the heat in the forge (coquitur dum massa camino, 10) but food is also cooked over heat (coquitur).

\section{Lines 14-16: A positive definition of Persius' style and theme}

Although he will return to the obsolete themes and style of contemporary literature in 17-18, Cornutus interrupts his criticism to remind Persius of his literary programme and to give a positive definition of the poet's style and theme:

14 uerba togae sequeris iunctura callidus acri,

15 ore teres modico, pallentis radere mores

16 doctus et ingenuo culpam defigere ludo.

You keep to the dress of everyday speech, but you're clever at the pointed juxtaposition; / you've a fairly well-rounded diction; you're adept at scraping unhealthy habits / and nailing vice with a stroke of wit.

These are the most important lines in the first section of Satire 5 since they are the most forthright exposition of the style and content of Persius' satires. In these programmatic lines Cornutus states that Persius' style concurs with the simple, unadorned, and presumably earnest style of the average citizen: it is Persius' task to criticise his reader / mankind, and his style is the plain language of everyday life — uerba togae (14) and also plebeia ... prandia (18), which represents a continuation of the metaphor of poetic food - in order to reach not only the sophisticated reader, but also and above all the ordinary citizen.

These lines might refer to the contrast between satire, the truly Roman genre, and epic and tragedy, the (foreign) Greek genres. This contrast would then be implied by uerba togae (also associated with the fabula togata, comedy that was Greek in form but in which the characters and life presented were Roman as in contrast to the fabula praetexta) and ingenuo (16; native, indigenous, not foreign) as opposed to the reference to the Greek genres in Mycenis (17). I will come back to these lines in a moment.

\section{Lines 17-18: Cornutus warns the poet against tragedy}

17 hinc trahe quae dicis mensasque relinque Mycenis

18 cum capite et pedibus plebeiaque prandia noris.’

Draw your material from there. Leave to Mycenae its menus / of heads and feet, and get used to common food."

Cornutus concludes his criticism of contemporary themes and style by advising Persius to ignore the gruesome themes of tragedy like the meal of Thyestes and to get to know the dinners of the common Roman people.

Harvey (1981:132) says that hinc does not refer to anything explicit, but to the idea of "moralising themes" implied in the preceding lines. It is my suggestion that hinc could in the first place be interpreted as referring to the three aspects of the style and content of Persius' poetry explained in 14-16: his skill and dexterity in cleverly fusing words (iunctura callidus acri, 14), his moderate and rounded style (ore teres modico, 15), and his intention to give his 
work a moral flavour (doctus, 16). It is these three principles that Persius adhere to when composing his satire and on these principles (hinc) he bases his poetry (quae dicis, 17).

Secondly, hinc could also be interpreted as referring to the traditional Roman values (as expressed in uerba togae sequeris, 14 and ingenuo, 16, i.e. "native”, "Italian”: similarly, Camena, 21 refers to the Italian rather than the Greek Muse). These values are the opposite of those referred to in Mycenis (17), representing Greece and all it stands for: Mycenis is of course the scene of Thyestes' grim meal (8), a reminder of the unreality of tragedy.

This contrast between native Roman values and foreign un-Roman values is also suggested by the contrast between mensas (17) and prandia (18). With mensas, Cornutus refers to the meal of Thyestes (olla Thyestae, 8) or more specifically, to the gruesome themes treated by tragedy such as the cannibalistic meals of Procne and Thyestes. Mensas also refers to cenae which is implied by cenanda (9), indicating the luxurious and excessive evening meal during which plays or extracts from plays were often presented or recited. Prandia, on the other hand, refers to the simple unceremonious meal usually taken at or soon after noon. The prandium often consisted of nothing more than a piece of bread, but was more usually accompanied by cold meat, vegetables, and fruits washed down with a little wine (Mart. 1.49.14). The meal was so quickly disposed of that there was no need to set a table beforehand or to wash the hands afterwards: Sen. Epist. 83.6; post quod non sunt lauandae manus.

The contrast between mensas (17) and prandia (18) therefore points to the opposition between banquets (mensas) of an unnatural sort in the heroic ages of Mycenae, known in these days only as stage-horrors with no lesson for life, and everyday meals (prandia, not cenae) of the simplest kind among common society at Rome, which show ordinary men as they are.

Returning to his original imagery, Cornutus contrasts tragedy and satire in terms of food. He associates tragedy with cannibalistic banquets by reminding the reader of the menu of the gruesome banquet: mensas ... / cum capite et pedibus (17-18). These are especially mentioned because they were put aside (Seneca Thyest. 764, tantum ora seruat et datas fidei manus) and later brought to Thyestes to show him what he really had been eating. The satirist on the other hand eats the food of the people (Némethy 1903:242), plain, modest, and therefore irreproachable: plebeiaque prandia noris. Scorning the tragedian's cena, therefore, Cornutus recommends to his pupil modest meals (plebeia ... prandia), that is, a style representing popular speech.

The separate images of a poet supplying large amounts of tragic and epic food (5-6), of tragedians cooking children (8-9), and of an actor presenting these gruesome dishes of human flesh at the cena (9), are compressed into mensas ... Mycenis (17), so that tragedy is represented as a vast, grisly meal (Bramble 1974:56; Harvey 1981:132). The phrase mensas ... Mycenis becomes metaphorical for contemporary literature. Following on from this, Persius can depict satire as normal, everyday food since the recurring images of poetry as food and of poetry as hot air $(7,10-11)$ characterise epic and tragedy as insubstantial, a mere "banquet of tasty phrases” (Dessen 1968:72).

The importance of these lines lies in the fact that the metaphors give a rounded verdict on the nature of tragedy and satire, although literature is not expressly mentioned in 17-18. The high genre (here referring to tragedy: mensas . . Mycenis / cum capite et pedibus, 17-18) is questionable because of its coarseness and tumid gravity (10-13). Satire, on the other hand, relies for its superiority on the virtue of humility and modesty: in getting to know or preparing the food of the people, Persius represents himself as an unassuming realist. 
His poetry is not appropriate for the excessive cena (implied by cenanda, 9) during which the gruesome themes of Greek tragedy (mensas, 17) were presented, for the food served at the cena is not wholesome (robusti carminis offas, 5; Procnes aut . . olla Thyestae / feruebit, 8-9), it is like hot air (nebulas, 7; tu neque anhelanti, coquitur dum massa camino, / folle premis uentos, 10-11) and it is inflated (nec scloppo tumidas intendis rumpere buccas, 13). No, Persius is writing for a different kind of audience, presenting simple and modest fare (plebeia ... prandia, 18).

\section{6. $\quad$ Lines 19-25: Persius replies to Cornutus’ speech}

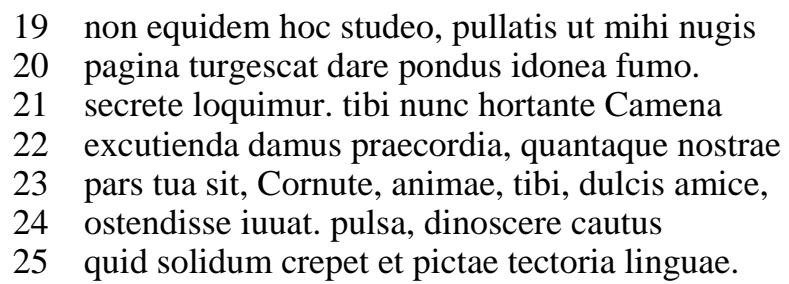

It's certainly not my aim to swell my page with frivolities dressed up in mourning in the hope of lending weight to smoke. What I have to say is private. Now, with the Muses's encouragement, I'm offering my conscience to you, Cornutus, for a thorough inspection. I want to show you, my dear friend, how much of my soul belongs to you. Go on - tap it. You're an expert at telling what sounds solid from painted stucco put on by the tongue.

In the first section of his reply (19-25) to Cornutus' interruption (5-18), Persius narrows his focus from literature in general to the specific occasion of expressing his debt to Cornutus. He firstly admits that he is not concerned with empty words (pullatis . . nugis, 19). He therefore has no desire to let his pages swell with trivialities fitted only to give weight to smoke (20): the bombastic themes of tragedy are not for him, but his words are for a select audience (secrete loquimur, 21). Having established this and having dissociated himself from the Greek genres of epic and tragedy (7), Persius narrows his focus from literature in general to claim the encouragement of the Muse of Roman poetry (hortante Camena, 21) for he intends to reveal his innermost feelings (praecordia, 22) about Cornutus and to assure him of his sincerity which Cornutus may test for solidity (pulsa, 24) as one might test a plastered wall (25).

\section{7. $\quad$ Lines 26-29: Persius refers back to the opening lines}

26 hic ego centenas ausim deposcere fauces,

27 ut quantum mihi te sinuoso in pectore fixi

28 uoce traham pura, totumque hoc uerba resignent

29 quod latet arcana non enatrabile fibra.

For this I would venture to ask for a hundred throats / that, however firmly I have tucked you inside my heart's folds / I may draw you out in clear tones, and my words may reveal / what lies obscure and inexpressible within my deepest fibres.

Persius finally discloses the real reason for having mentioned a 100 tongues (1-4) - he is revealing the secrets of his heart (praecordia, 22) for which he cannot use the high style and 
contemporary topics. Cornutus has taught him the essential style and themes for satire (1416) that is to be presented at the prandium (18) with its simple fare instead of the fabula ... hianda (3), uolnera ... Parthi (4) and olla (8) presented at the excessive and luxurious cena by his contemporaries. And now that Cornutus as friend and literary critic has tested his sincerity (19-25) he not only wants to prove that he had taken the instruction seriously, but also to express his love and respect for Cornutus and the closeness of their friendship (quantum mihi te sinuoso in pectore fixi, 27) which is immeasurably beyond the power of one voice (hic ego centenas ausim deposcere fauces, 26). But the poet's emotions do not spring from the mouth; they have established themselves permanently in his heart (in pectore fixi, 27). Therefore, the revelation (uoce ... pura, 28) of his natural affection can be characterised in contrast to the undisciplined bursting and popping of the poet's cheeks (13): totumque hoc uerba resignent / quod latet arcana non enarrabile fibra (28-29).

The use of fauces ("throat”, 26) reflects Persius' unique application of the 100-mouth theme to the expression of deeply held convictions, since it is not a traditional term in this formula. Cornutus - and his teachings (for above all Cornutus is an embodiment of the Stoic way of life) - is lodged deep within the heart of his pupil. The poetry which that pupil writes is the result of intense personal probing; the struggle to realise those probings uoce ... pura and undergo the effort involved in traham (28), a word which is descriptive of the struggle to elicit internal feelings, is the only way of bringing forth that which is normally hidden from view (Bramble 1974:9).

\section{Conclusion}

The first 29 lines of the satire constitute Persius' dismissal of the themes and style used by his contemporaries for writing traditional epic and tragedy, and at the same time constitute a confirmation of the kind of poetry that he is writing. The theme of Persius' dissociation from traditional literary themes and values is continued throughout these lines by way of references with pejorative connotations to the themes and style of contemporary literature. In the poet's dialogue with Cornutus, epic and tragedy are equated with the preparation and consumption of food and poetry is also described in terms of hot air.

The whole passage is an important and brilliant statement about the purpose of Roman satire, and it expresses more comprehensively the ideas sketched in the prologue and the first satire. Persius justifies his dissociation from the more widely read genres of tragedy and epic. As befits the friend and student of the great critic Cornutus, he claims that his poetry is sincere, lacking in the gruesome attractions of contemporary literature. Sincerity of expression means trying to put into words thoughts that lie too deep for facile expression (29) and this, too, justifies the complexity of his satiric style. Thus, Persius builds on the work of his great predecessor, Horace, and justifies his own innovations in the genre of Latin satire (Morford 1984:56-57).

\section{BIBLIOGRAPHY}

Anderson, W S 1960. Part versus whole in Persius' fifth satire. PhQ 39:66-81.

Bo, D 1969. A. Persi Flacci Saturarum Liber. Torino: Paravia.

Bramble, J C 1974. Persius and the programmatic satire: a study in form and imagery. Cambridge:

University Press. 
Clausen, W V 1959. A. Persi Flacci et D. Iuni Iuvenalis Saturae (repr. 1968). Oxford: Clarendon Press.

Conington, J \& Nettleship, H 1874. The Satires of A. Persius Flaccus ( $2^{\text {nd }}$ ed.). Oxford: Clarendon. Dessen, C S 1968. Iunctura callidus acri: a study of Persius' satires. Urbana: Illinois Studies in Language and Literature 59.

Harvey, R A 1981. A Commentary on Persius. Leiden: Brill.

Morford, M 1984. Persius. Boston: Twayne.

Némethy, G 1903. A. Persii Flacci Satirae. Budapest: Hungarian Academy.

Pretor, A 1907. A. Persii Flacci Satirarum Liber. Cambridge: Bell.

Ramage E S 1979. Method and structure in the satires of Persius. ICS 4:136-151.

Rudd, N 1979. Horace: Satires and Epistles; Persius: Satires. Harmondsworth: Penguin Books.

Van Wageningen J 1911. Auli Persi Flacci Saturae (2 vols.). Groningen: Noordhof. 